\title{
PERGULATAN IMAN BUDHI SANTOSA UNTUK MENCAPAI POSISI TERKONSEKRASI DALAM ARENA SASTRA YOGYAKARTA
}

\author{
Anggun Nirmala Safitri \\ Fakultas Sastra Universitas Jember \\ Email: njun.ideas@gmail.com
}

\begin{abstract}
Abstrak
Artikel ini berusaha mengungkap bagaimana pergulatan Iman Budhi Santosa dalam arena sastra Yogyakarta untuk mencapai posisi sastrawan terkonsekrasi. Teori Arena Produksi Kultural Bourdieu dirasa tepat untuk membongkar relasi antarobjek yang mengarahkan Iman menjadi sastrawan terkonsekrasi dalam arena sastra Yogyakarta. Dengan konsep habitus, modal, strategi, praktik dan lintasan, relasi-relasi antar objek yang mengarahkan dan atau mendukung posisi Iman untuk menjadi sastrawan akan diidentifikasi. Praktik sastra yang termanifestasi dalam kegiatan penulisan dan penerbitan karya, keikutsertaan dalam kegiatan, pembentukan lembaga, merupakan tumpukan modal simbolis yang membuat Iman menduduki posisi sastrawan yang terkonsekrasi dalam arena sastra Yogyakarta.
\end{abstract}

Kata kunci: Iman Budhi Santosa, Bourdieu, Arena Produksi Sastra, habitus, modal, strategi, praktik dan lintasan.

\section{Abstract}

This article tries to uncover the struggle of Iman Budhi Santosa to reach the dominant position in the field of Yogyakarta literature. Bourdieu's theory, the field of cultural production, is used to uncover the relation between objects that support Iman to become a consecrated poet in the field of Yogyakarta literature. The relation of the objects are explained by the concepts of habitus, capital, strategy, practice, trajectory.Literary practices which are manifestated in the form of literary writing and publishing activities, the participation in literary activities, institution forming in Yogyakarta are accumulated as symbolic capital which directs his possition to become a consecrated poet in Yogyakarta.

Keywords: Iman Budhi Santosa, Bourdieu, the field of cultural production, habitus, capital, strategy, practice, trajectory

\section{Pendahuluan}

Dalam khazanah kesusastraan

Yogyakarta kontemporer, nama Iman Budhi Santosa termasuk ke dalam nama-nama sastrawan yang telah diakui. Saat ini Iman dikenal sebagai sastrawan senior di Yogyakarta. Selain menulis karya sastra, ia juga terlibat dalam kegiatan-kegiatan yang berkaitan dengan sastra. Saat ini, selain tetap menulis, Iman menjadi pembina Komunitas Gubuk Indonesia (KGI) dan penasihat Forum Musyawarah Seniman Budayawan Muslim 'Langgar Dhuwur' Yogyakarta. Saat ini ia juga menerbitkan majalah Sabana yang ia dirikan bersama temannya, budayawan Emha Ainun Nadjib. Iman bukan hanya sastrawan yang menelurkan karya, tetapi juga membentuk komunitas, mendirikan perkumpulan, menjadi penasihat dan pembina dalam berbagai kelompok. Banyak sastrawan muda yang berguru kepadanya. Apabila dilihat dari posisi-posisi yang ditempatinya dalam khazanah sastra Yogyakarta, bisa dikatakan bahwa Iman adalah salah satu tokoh yang berpengaruh di dalamnya.

Posisi yang dicapai oleh Iman dalam dunia sastra Yogyakarta tentu saja tidak akan dapat dipisahkan dengan kualitas-kualitas yang dimiliki Iman, seperti kemampuan kognitif yang dimilikinya, pengetahuan tentang sastra, tindakan yang dilakukan, orang-orang yang berada di sekitarnya, kelompok-kelompok dan institusi di sekelilingnya, serta media yang mendukung Iman menjadi sosok terlegitimasi dalam dunia sastra. Penelitian ini berusaha mengungkap bagaimana relasi dari beberapa poin di atas mengarahkan Iman mencapai posisi dominan dalam arena sastra Yogyakarta.

Teori Arena Produksi Kultural Bourdieu dirasa tepat digunakan untuk mengungkap bagaimana struktur sosial bekerja. Dalam 


\section{Jurnal Poetika Vol. III No. 2, Desember 2015}

struktur sosial ini terjadi pergulatan antarindividu untuk mencapai posisi dominan secara sosial. Bourdieu menyebut tempat pergulatan ini sebagai arena, sedangkan individu, kelompok dan instansi yang bergulat untuk memperebutkan dominasi ini disebut sebagai agen. Tiap agen ini memiliki kognisi yang berbeda, distrukturkan oleh struktur sosial yang melingkupinya. Kognisi ini disebut sebagai habitus yang merupakan kumpulan disposisi tak sadar yang memproduksi strategi. Strategi ini mengarahkan praktik agen untuk mencapai posisi tertentu dalam arena. Tiap agen juga diwarisi modal berupa modal ekonomi, sosial, kultural dan simbolis yang dipertukarkan maupun diakumulasi untuk mecapai posisi terkonsekrasi. Untuk mencapai posisi tersebut terdapat lintasan yang dilewati oleh agen, yaitu perpindahan dari posisi ke posisi hingga mencapai posisi terlegitimasi.

Pergulatan Iman dalam mencapai posisi sastrawan terkonsekrasi akan dianalisis menggunakan teori ini, dengan menjelaskan awal mula pembentukan habitus, modalmodal yang dimiliki olehnya, strategi yang digunakannya, praktik sastra yang dilakukan, serta lintasan dan posisi yang ditempati Iman secara berganti sehingga menempati posisi sastrawan terkonsekrasi.

\section{Pierre Bourdieu: Arena Produksi Sastra}

Kerangka teoritis yang digunakan dalam penelitian ini adalah Teori Arena Produksi Kultural. Dalam analisis sastra, arena yang dimaksud adalah arena produksi sastra. Melalui teorinya ini, Bourdieu berusaha membongkar mekanisme yang bekerja dalam dunia sastra termasuk di dalamnya bagaimana proses individu untuk mendapatkan pengakuan sebagai seorang sastrawan. Dalam pemikirannya, Bourdieu berusaha menjembatani dikotomi antara subjektivisme dan objektivisme.

Subjektivisme merupakan paham yang menganggap bahwa pengetahuan bersifat subjektif. Dalam pandangan ini, pengetahuan didasarkan pada persepsi individu, meliputi fenomenologi juga pendekatan sastra ekspresif yang menganggap karya sebagai ekspresi dari pengarang. (Bourdieu, 2012:xiii) Sebaliknya, objektivisme menekankan pada relasi-relasi objektif yangmenstrukturkanpemikiran manusia. Subjektivisme mengabaikan realitas sosial yang menstrukturkan kesadaran manusia, sedangkan objektivisme melupakan konstruksi individu terhadap realitas sosial. Bourdieu menjembatani dikotomi keduanya dengan menyatakan bahwa individu memiliki andil dalam mengonstruksi realitas sosial masyarakat meskipun realitas sosial juga yang menstrukturkan pemikiran individu. Dari sini terlihat bahwa Bourdieu menganggap bahwa antara individu dan masyarakat bukan dua hal yang terpisah, melainkan dua hal yang saling mempengaruhi.

Terdapat beberapa konsep penting dalam pemikiran Bourdieu tentang arena produksi sastra, yaitu arena, habitus, kapital, strategi, praktik dan lintasan. Arena menurut Bourdieu dalam Haryatmoko (2010: 9) adalah ruang-ruang yang merupakan tempat perjuangan antarindividu dan kelompok untuk memperebutkan dominasi terhadap objek yang menjadi perebutan. Objek ini tidak selalu berupa materi. Arena produksi kultural adalah sebuah ruang yang disebutkan sebelumnya dimana yang diperebutkan adalah posisi-posisi dominan yang memiliki legitimasi terhadap budaya termasuk seni dan sastra. Karnata (2013: 7) menyatakan bahwa "taruhan utama dalam arena sastra adalah monopoli legitimasi sastra, yakni monopoli kekuasaan untuk mengatakan berdasarkan otoritas siapa yang berhak menyebut dirinya penulis yang mana salah satunya ditunjukkan oleh pergulatan antara penulis muda dan penulis senior yang sudah terkonsekrasi". Kontestasi ini menyebabkan perubahan-perubahan dalam arena, munculnya jenis sastra yang baru dan dilegitimasi, menggeser jenis sastra yang sebelumnya dominan. Terjadi proses penuaan dan produksi sastra yang dinamis di dalamnya.

Individu-individu atau kelompokkelompok yang bersaing dalam arena sastra ini 


\section{Jurnal Poetika Vol. III No. 2, Desember 2015}

oleh Bourdieu disebut sebagai agen. Tiap agen memiliki kualitas-kualitas yang ada di dalam maupun di luar dirinya yang melekat padanya. Kualitas-kualitas inilah yang digunakan oleh agen untuk bersaing dalam arena. Bourdieu menyebut kualitas-kualitas ini sebagai kapital atau modal dan habitus.

Modal merupakan sumber daya yang dimiliki agen yang dimanfaatkan dalam mencapai posisi tertentu dalam arena. Modal dibagi menjadi empat, yaitu modal ekonomi, modal sosial, modal budaya, dan modal simbolik. Modal ekonomi merupakan modal yang berupa materi maupun uang. Modal ini merupakan modal yang paling mudah dikonversi ke dalam bentuk modalmodal yang lain, juga diwariskan. Modal sosial merupakan relasi-relasi, jaringan sosial yang dimiliki oleh agen yang mampu membawanya pada posisi yang diperjuangkan dalam arena. Modal budaya merupakan keseluruhan kualifikasi intelektual yang bisa diproduksi oleh pendidikan formal maupun keluarga (Karnata, 2013:11). Terakhir adalah modal simbolik, yaitu prestise, pengakuan, status, dan otoritas. Modalmodal ini oleh agen bisa ditukarkan (konversi) ke dalam bentuk modal lain yang lebih sesuai dengan kebutuhan arena dan atau dapat pula dikumpulkan (akumulasi).

$$
\begin{array}{ll}
\text { Habitus merupakan akumulasi } \\
\text { internalisasi pengetahuan agen yang }
\end{array}
$$
diperolehnya sejak lahir yang kemudian membentuk kepribadiannya. Pengetahuan yang menstrukturkan kepribadian agen ini kemudian menstrukturkan cara agen dalam berinteraksi dengan kenyataan objektif. Habitus merupakan sekumpulan disposisi yang secara tidak disadari maupun disadari mengarahkan tindakan agen. Habitus muncul dalam respon-respon dan tindakan praktis agen dalam berinteraksi dengan realitas seperti yang dikatakan Haryatmoko, "kerangka penafsiran untuk memahami dan menilai realitas dan sekaligus penghasil praktikpraktik kehidupan yang sesuai dengan strukturstruktur objektif." Habitus agen ini menghasilkan strategi disesuaikan dengan realitas yang dihadapinya.

Apabila habitus merupakan sekumpulan kompetensi yang membentuk agen yang juga ikut menentukan respon agen terhadap situasi atau realitas yang dihadapinya, strategi adalah produk habitus. Strategi merupakan pengarahan tidak sadar terhadap praktik agen untuk mencapai posisi tertentu. Agen memprogram (secara sadar maupun tidak sadar) strategi-strategi spesifik guna mentransfer modal-modal yang dimilikinya sebagai praktik untuk mencapai posisi tertentu dalam arena. Strategi mengarahkan praktik agen berdasarkan habitus dan modal untuk mendapatkan solusi paling memungkinkan dalam kondisi arena yang penuh perjuangan.

Dalam usahanya untuk mencapai posisi tertentu dalam arena, agen menggunakan strategi untuk mengarahkan habitus dan modalnya untuk dipertukarkan, diakumulasi atau dengan istilah lain diinvestasikan. Dalam arena, agen berpindah dari posisi sosial yang satu ke posisi sosial yang lain dan akhirnya sampai pada posisi yang dominan. Perpindahan posisi inilah yang disebut trajektori, lintasan dimana agen melakukan mobilitas dari posisi satu ke posisi lainnya hingga mencapai posisi yang diinginkan, yaitu posisi yang dominan dalam arena.

\section{Pergulatan Iman Budhi Santosa dalam Mencapai Posisi Terkonsekrasi dalam Arena Sastra Yogyakarta}

\section{Asal Muasal Disposisi}

Iman lahir dalam lingkungan keluarga priyayi. Ia berasal dari keluarga berpendidikan. Kakeknya adalah seorang kepala sekolah di Magetan. Iman mengakui bahwa dia tidak bercita-cita untuk menjadi sastrawan. Pengaruh kuat terhadap Iman yang kemudian mengarahkan Iman pada dunia tulis-menulis adalah kakeknya. Kakek Iman menjadi sosok yang berpengaruh karena sejak Iman kecil, kakeknya sering memberikan pertanyaan-pertanyaan filosofis untuk merangsang pemikiran Iman. Pertanyaanpertanyaan seperti, "Kenapa kucing tidak mati 


\section{Jurnal Poetika Vol. III No. 2, Desember 2015}

di sembarang tempat? Di mana bangkai manuk emprit yang mati karena usia bukan karena dibunuh? Pertanyaan-pertanyaan semacam itu mengganggu, menimbulkan kegelisahan dalam diri Iman kecil dan terus berlanjut sampai kakek iman meninggal saat Iman kelas dua sekolah menengah pertama. Kegelisahan inilah yang menjadi cikal bakal karir kepenulisan Iman. Baginya, menulis menjadi semacam penyaluran kegelisahan-kegelisahan yang menumpuk dalam hati dan pikirannya.

Meskipun kakeknya merupakan orang yang paling berperan dalam menanamkan kegelisahan pada Iman, Ibu Iman juga berpengaruh. Pada saat Iman masih duduk di bangku Sekolah Dasar, tepatnya saat kelas 4 Sekolah Rakyat (sekarang Sekolah Dasar), ibunya membujuk Iman untuk menulis sebuah cerita. Tanpa sepengetahuannya, tulisannya dimuat di Majalah Taman Putra. Oleh karena itu, ibunya juga turut andil dalam memberikan dasar bagi karir kepenulisan Iman.

Sebagai seorang sastrawan, Iman terkenal sebagai sastrawan yang sengit terhadap sistem birokrasi juga aristokrasi. Disposisi ini didapatkannya ketika ia masih kecil. Ia diberi tahu oleh kakeknya bahwa ia selayaknya bersyukur karena dapat bersekolah di sekolah buatan Belanda karena pemimpin Jawa tidak membuatkan sekolah bagi rakyatnya. Ia tidak senang mendengar bahwa yang memberikan pendidikan bagi rakyat adalah bangsa asing, bukan pemimpinnya sendiri. Mulai dari itu ia sengit terhadap bangsawan beserta pemerintah dan sistem pemerintahannya. Ketidaksenangannya pada aristokrasi dan sistem pemerintahan pula yang mengarahkan karya-karyanya pada tema masyarakat pinggiran.

Dengan demikian, disposisi awal yang mengarahkan Iman pada posisi sastrawan adalah kegelisahan yang ditanamkan oleh kakeknya masih belum menemukan muara. Bujukan ibunya untuk menulis dan diterbitkan di majalah juga merupakan bentuk awal praktik menulis karya yang dilakukan oleh Iman. Sementara itu, ketidaksenangan dengan aristokrasi dan sistem pemerintahan ia peroleh dari pengetahuannya saat kecil bahwa sekolahnya merupakan buatan Belanda, bukan kerajaan.

\section{Membentuk PSK}

PSK (Persada Studi Klub) merupakan komunitas sastra yang terbentuk pada tahun 1968. PSK dibentuk di kantor mingguan Pelopor Yogya, Jalan Malioboro 175 A. PSK lahir pada masa awal pemerintahan Orde Baru (1966-1998). Iman adalah satu dari beberapa nama yang ikut andil dalam membentuk PSK. Beberapa tahun sebelum kelahiran PSK, arena sastra didominasi oleh kelompok realisme sosialis yang merupakan corong komunisme. Pada masa itu juga terjadi pembantaian PKI yang juga merembet pada pembubaran Lekra. Tekanan dari pemerintah pada waktu itu terhadap karya-karya berbau politis juga turut mengubah kecenderungan arena sastra. Arena sastra menjadi apolitis sejak penulis-penulis yang kritis terhadap pemerintahan Orde Baru ditangkap dan karya mereka dibredel.

PSK tumbuh pada masa-masa itu. Kondisi sosial dan politik yang demikian mempengaruhi arah kebudayaan di dalam sastra. Sastra yang muncul tidak berbau politis. Perkembangan sastra diarahkan pada estetika sastra dan lebih berbau humanisme. Semangat kolektivitas kepenyairan Yogya kembali tumbuh subur, yang langsung tak langsung merupakan rekondisi terhadap jagat kesastraan di Yogya, yang sebelumnya sangat didominasi oleh politik realisme sosialis kepartaian (Asmara, 2010:18). Dalam komunitas ini, penyair-penyair muda didorong untuk menemukan tema-temanya sendiri dengan Umbu sebagai guru, motivator, apresiator sekaligus pengasuh rubrik sastra dalam mingguan Pelopor Yogya.

Penyair-penyair muda yang tergabung dalam PSK ini kebanyakan idealis, tidak mementingkan materi dan pendidikan formal. Di Maliboro mereka menggelandang, memahami kehidupan orang-orang kecil seperti 


\section{Jurnal Poetika Vol. III No. 2, Desember 2015}

gelandangan, pengemis dan tukang becak, orang-orang yang termasuk ke dalam kelompok marjinal untuk memasukkannya ke dalam karya mereka. Karya-karya yang mereka hasilkan pun tidak selalu menghasilkan materi. Bahkan, apabila mereka mendapatkan honor pun kadang untuk mentraktir teman-teman sekelompok. Di saat orang-orang berlomba untuk mendapatkan kenyamanan dan kelimpahan materi, mereka lebih menghargai kreativitas daripada pekerjaan, mengutamakan proses daripada tujuan.

Hal ini sesuai dengan hukum dasar arena sastra yang disebutkan oleh Bourdieu yaitu arena produksi enomomi terbalik. Disebut sebagai arena produksi terbalik karena adanya penolakan terhadap laba ekonomi jangka pendek oleh agen dalam arena produksi sastra. Kegiatan produksi dalam arena sastra tidak ditujukan untuk mendapatkan laba ekonomi. Akan tetapi, penolakan yang konsisten terhadap laba jangka pendek ini kemudian dapat berubah menjadi laba simbolik jangka panjang dan membuat para pelakunya mendapatkan pengakuan dari agen-agen lainnya dalam arena di kemudian hari. Dalam hal pendidikan, PSK menganggap bahwa pendidikan formal hanya mereproduksi struktur masyarakat yang telah ada sebelumnya. Umbu memberikan model pendidikan alternatif dengan partisipasi secara langsung dengan realitas. Realitas dirasakan, dipahami secara nyata, bukan dari bangku perkuliahan.

Iman yang lama berproses di PSK sedikit banyak juga terpengaruh dengan pemikiranpemikiran yang seperti itu. Ia memperoleh disposisi keberpihakan terhadap masyarakat kecil dan sikap yang kurang menghargai sistem pendidikan. Pada lintasan ini terjadi pertambahan modal pada Iman yang awalnya anak sekolahan lulusan S.Pb.M.A. 4 th, Yogyakarta. Dia menumpuk modal kultural dan modal sosial dalam PSK. Modal kultural berupa pengetahuan tentang sastra yang diperolehnya dari Umbu dan interaksinya dengan anggota komunitas lainnya. Di dalam PSK lah kegelisahan-kegelisahan yang dulu ditanamkan oleh kakeknya yang seiring pertambahan usianya bertambah mendapatkan bentuk yaitu karya sastra, khususnya puisi.

Lebih dari itu, ia pun mendapatkan modal sosial berupa jaringan pertemanan antara anggota PSK yang anggotanya berlipat hingga mencapai 1.555 orang. Modal sosial ini akan berguna di kemudian hari saat ia tetap bertahan di lintasan arena sastra. Orang-orang ini lah yang juga berkontribusi dalam mengarahkan posisi Iman sebagai sastrawan terkonsekrasi.

\section{Bekerja untuk Menumpuk Modal Kultural}

Sepeninggal Umbu Landu Paranggi pada tahun 1975, PSK mulai mundur hingga akhirnya berhenti sama sekali. Pada tahun itu pula Iman meninggalkan Yogya untuk bekerja pada Dinas Perkebunan Provinsi Jawa Tengah. Di sana ia bekerja sebagai mandor di perkebunan dengan bawahan sekitar seribuan. Pekerjaan sebagai mandor menuntutnya untuk dapat berinteraksi dengan baik dengan anak buahnya. Iman pun mengaku ia melakukan pendekatan pada seluruh bawahannya dengan berbagai macam cara mulai dari ngopi sampai gaple (domino).

Kedekatan dengan masyarakat kecil ini sebenarnya sudah mulai tumbuh sejak disposisi yang ditanamkan dalam PSK. Akan tetapi, kedekatannya yang intens dengan buruh ini memperkuat keterikatan Iman dengan masyarakat kecil yang kemudian juga menjadi salah satu tema sentral dalam karya-karyanya. Sedangkan disposisi ketidaksukaannya pada pemerintah yang tertanam sejak kecil, pada tahap ini mengambil bentuknya dengan ketidaksepahaman yang sering terjadi antara Iman dengan para petinggi di kantornya.

\section{Akumulasi Modal Simbolis}

Pada tahun 1986, Iman kembali ke Yogyakarta atas undangan Suryadi untuk menghadiri acara pembacaan sajak. Setelah itu ia tidak kembali lagi ke hutan. Menurut Iman, ia tidak cocok bekerja dalam struktur. Ia mengatakan bahwa saat bekerja, ia sering bersitegang dengan atasan. Ia tidak memiliki 


\section{Jurnal Poetika Vol. III No. 2, Desember 2015}

masalah dengan bawahan, malah cenderung akrab. Maka ia memutuskan untuk kembali ke Yogya menjadi anggota masyarakat pinggiran, yaitu sastrawan.

Iman mengakui bahwa sekembalinya ke Yogyakarta, yang pertama dilakukan adalah berkunjung, menyapa kawan-kawan lama yang dulu sempat berproses bersama. Di Yogya, dia mulai kembali aktif bersastra. Terbukti sejak itu karya-karya sastra, buku-buku antologi bersama maupun individu mulai terbit, seperti Tugu (Dewan Kesenian Yogya, 1986), Tonggak 3 (Gramedia, 1987), Pesta Api (Swadaya, 1989). Meskipun saat di PSK dulu karya-karyanya juga telah terbit seperti Tiga Bayangan/puisi (Persada Studi Klub, 1970), Ranjang Tiga Bunga/novel (Indah, 1975), Barong Kertapati/novel silat (Indah, 1976) dan banyak tulisan yang muncul di media, namun baru pada masa ini karya-karyanya terus muncul sampai saat ini. Meskipun pada tahuntahun antara 1982-1985 ia juga menuliskan karya, tetapi karya-karya ini berupa karya ilmiah tentang perkebunan, bukan sastra.

Saat ini Iman bisa dianggap sebagai sastrawan senior di Yogyakarta, dilihat dari rentang produktivitasnya yang dimulai dari sejak keanggotaannya dalam PSK. Meskipun sempat vakum selama sembilan tahun, tetapi sekembalinya Iman ke Yogya juga ke dalam dunia sastra, produktivitasnya terus berjalan secara kontinyu hingga saat ini.

Tulisan-tulisannya telah tersebar dalam berbagai media massa. Sebagai penulis, Iman cukup kompleks. Tidak hanya menulis karya sastra, ia juga menulis esai-esai kebudayaan, sosial, bahkan latar pendidikan tinggi di bidang pertanian dan pekerjaan formalnya selama beberapa tahun di perkebunan memberi dia dasar untuk menulis karya ilmiah tentang perkebunan. Karya-karya Iman lainnya juga banyak yang diterbitkan, antara lain berupa antologi puisi bersama, antologi puisi individual, cerpen, cerkak Jawa, esai sastra, cerita rakyat, novel, novelet, bahkan sampai geguritan. Sejak 1969, penghargaan-penghargaan dalam bidang sastra telah banyak yang diraihnya. Ulasan-ulasan tentangnya maupun tentang tulisannya telah muncul dalam berbagai media. Posisinya sebagai sastrawan juga didukung dengan pengakuan oleh sastrawan-sastrawan yang juga rekan dalam arena sastra Yogyakarta. Lebih-lebih, pencantuman namanya dalam beberapa buku biografi sastrawan, baik lokal maupun nasional, telah mengukuhkan dirinya menjadi seorang sastrawan yang diakui.

Posisi Iman ini tidak dapat dilepaskan dari agen-agen yang mendukungnya untuk mencapai posisi tersebut. Terutama kawankawannya yang dulu di PSK dan saat ini telah memiliki nama secara nasional, seperti Korrie Layun Rampan, Emha Ainun Nadjib, dan Linus Suryadi (alm). Salah satu bentuk legitimasi adalah yang diberikan oleh Emha. Meskipun Emha tidak secara spesifik bergerak dalam ranah sastra, budayawan sekaligus pemerhati politik ini memliki masa yang tak terhitung banyaknya. Saat ia menuliskan tentang Iman, secara otomatis nama Iman pun akan dikenal oleh orang-orang yang berada dalam kubu Emha.

Selain mendapatkan pengakuan dari sastrawan dan budayawan, keikutsertaan aktif Iman dalam kegiatan-kegiatan yang berkaitan dengan sastra juga turut memperkuat posisi Iman dalam arena sastra Yogyakarta. Beberapa kegiatan Iman yang berkaitan dengan sastra adalah menyelenggarakan kegiatan diskusi sastra 'pengadilan puisi' (1989-1991) serta keterlibatan dalam FKY (Festival Kesenian Yogyakarta) sebagai ketua seksi Sastra Indonesia (19951997-1998). Keikutsertaan-keikutsertaan Iman dalam kegiatan sastra ini kemudian menambah kepercayaan masyarakat sastra terhadap Iman. Iman dilihat bukan hanya sebagai kreator melainkan juga seseorang yang peduli terhadap keberlangsungan sastra.

Hingga saat ini Iman masih aktif dalam kegiatan sastra dan budaya di YCK (Yayasan CempakaKencana), menjadipembinaKomunitas Gubuk Indonesia (KGI), menjadi penasihat Forum Musyawarah Seniman Budayawan 


\section{Jurnal Poetika Vol. III No. 2, Desember 2015}

Muslim 'Langgar Dhuwur' Yogyakarta. Posisi pembina dan penasihat merupakan posisi yang hanya dapat ditempati oleh-orang-orang yang dianggap telah melampaui proses di dalam kegiatan itu sendiri. Dalam posisi ini, Iman memiliki otoritas untuk memberikan legitimasi. Otoritas ini hanya dapat dimiliki oleh individu yang telah memiliki modal simbolis yang banyak, sehingga ia diakui sebagai sastrawan terkonsekrasi, memiliki otoritas penentu.

Lembaga dan institusi juga merupakan agen yang turut mengangkat posisi Iman. Iman turut mendirikan Yayasan Untuk Indonesia (YUI) pada 1996-2000 dan secara aktif menyelenggarakan kegiatan sastra dan budaya bersama YUI. Ia juga pernah aktif dalam Sanggar Studi Sastra dan Teater 'Sila', Bantul (19972002). Penunjukannya sebagai anggota Dewan Kebudayaan Yogyakarta seksi Bahasa dan Sastra Jawa (2004-2008) merupakan sebentuk kepercayaan yang diberikan pemerintah kota Yogyakarya kepada Iman yang menunjukkan bahwa Iman memiliki kapasitas dalam sastra. Bahkan, dalam kegiatan-kegiatan sastra yang diadakan Taman Budaya Yogyakarta (TBY), Dewan Kesenian Yogyakarta (DKY), dan kegiatan-kegiatan pemerintah yang berkaitan dengan sastra, Iman adalah salah satu orang yang ditemui untuk dimintai pendapatnya. Azwar (murid Iman) menyatakan, "Misalnya ada kegiatan sastra di Yogya dari Pemerintah, biasanya Pak Iman yang mengonsep." Ini berarti bahwa apa yang dikatakan Iman sedikit banyak memiliki pengaruh dalam kedua lembaga tersebut, lebihlebih terhadap kegiatan pemeriantah. Pengaruh Iman pada lembaga-lembaga yang berada dalam pusat pemerintahan mengukuhkan posisinya sebagi sastrawan terkonsekrasi. Dalam posisinya ini, Iman memiliki otoritas penentu dalam arena sastra.

Kumpulan disposisi yang tertanam pada Iman sejak kecil dan modalyang dimilikinya secara langsung maupun tidak langsung mengarahkan Iman untuk mencapai dominan dalam arena sastra Yogyakarta, mulai dari kegelisahan filosofis yang ditanamkan oleh kakek, keikutsertaannya dalam lomba semasa kecil, ketidaksukaannya pada aristokrasi dan birokrasi. Keterlibatannya dalam PSK yang membuatnya mendapatkan link teman-teman sastrawan, media, pemahamannya tentang masyarakat kecil, oposisi terhadap kegiatan politik dan ekonomi, kesemuanya menguatkan posisi Iman dalam sastra.

Meskipun Iman telah menerbitkan banyak karya, tetapi laba bukanlah tujuan utama yang ingin dicapai oleh Iman. Sastra hanyalah sarana untuk mengungkapkan kegelisahan, berkontribusi pada kemanusiaan, lebih-lebih juga sebagai ekspresi spiritual. Karya sastra digunakannya sebagai alat untuk menyampaikan pesan-pesan dengan cara yang mudah diterima. Hal ini sesuai dengan hukum arena sastra yang dinyatakan oleh Bourdieu, hukum ekonomi terbalik. Sastrawan menolak laba ekonomi yang berjangka pendek. Akan tetapi, apabila konsisten dan mampu bergulat dalam arena sastra yang memiliki hukumnya sendiri hingga mencapai posisi dominan, maka penolakan terhadap laba ekonomi jangka pendek ini akan berubah menjadi laba simbolik berupa prestis, status, otoritas yang kemudian dapat pula dikonversi menjadi laba ekonomi.

Praktik-praktik yang dipilih oleh Iman ini secara sadar maupun tidak sadar menambah modal-modal simbolik yang sebelumnya telah diakumulasinya. Dalam arena sastra, yang merupakan arena produksi terbalik bukan modal ekonomi yang memberikan legitimasi atau otoritas pada agen, melainkan akumulasi modal simbolik yang sering beroposisi dengan modal ekonomi dalam arena ini. Melalui praktik-praktik dan perpindahan dari posisi satu ke posisi yang lain, Iman mengakumulasi modal-modal simbolis tersebut sehingga ia dapat mencapai posisi sastrawan yang terlegitimasi.

\section{Kesimpulan}

Berdasarkan apa yang disampaikan di atas, diketahui bahwa posisi Iman Budhi Santosa sebagai sastrawan terkosekrasi tidak 
dapat dilepaskan dari relasi-relasi objektif yang terbangun di arena yang kemudian mengarahkannya untuk mencapai posisi terkonsekrasi dalam arena sastra. Akumulasi pengetahuan yang tertanam sejak kecil terutama latihan berpikir filosofis dari kakeknya serta dorongan untuk menulis dari ibunya memunculkan strategi pengolahan modalmodalnya untuk bergulat di arena sastra. Strategi pengolahan modal ini mengejawantahkan dirinya melalui praktik-praktik sastra yang mengarahkan Iman, seringnya secara tidak sadar, untuk berpindah dari posisi satu ke posisi yang lain dalam arena, membentuk lintasan hingga sampai pada posisi dominan, yaitu sastrawan terkonsekrasi dalam arena sastra Yogyakarta.

\section{Daftar Pustaka}

Anwar, Saeful. 2015. Persada Studi Klub dalam Arena Sastra Indonesia. Yogyakarta: Gadjah Mada University Press.

Asmara, Teguh Ranusastra. 2011. 'PSK Tonggak Kepenyairan Yogya" dalam Orang-

Orang Malioboro: Refleksi dan Pemaknaan Kiprah Persada Studi Klub 1969-1977 di Yogyakarta. Iman Budhi Santosa (Ed.). Format Microsoft Word (naskah praterbit).

Bourdieu, Pierre. 2010. Arena Produksi Kultural: Sebuah Kajian Sosiologi Budaya. (terjemahan Yudi Santosa). Yogyakarta: Kreasi Wacana Karnata, Kukuh Yudha. 2013. Paradigma Teori arena Produksi Kultural sastra: Kajian Terbadap Pemikiran Pierra Bourdieu. Dalam Poetika Vol. 1 No. 1, Juli 2013, hal. 1-14.

Widati, Sri, Tirto Suwondo, dan Herry Mardianto. 2008. Sastra Indonesia diYogyakarta Periode 1945-2000. Yogyakarta: Pusat Bahasa Balai Bahasa Yogyakarta.

https:// tumbuhkeatas.wordpress. com/2012/08/06/menelusuri-konflikkesusastraan-indonesia-lekra-vsmanikebu/ 